\title{
CLINICO-EPIDEMIOLOGICAL PATTERN OF POISONING IN A TERTIARY LEVEL HOSPITAL
}

\author{
HOWLADER MAR ${ }^{1}$, SARDAR MH ${ }^{1}$, AMIN MR $^{1}$, MORSHED MG ${ }^{2}$, ISLAM MS ${ }^{1}$ UDDIN MZ $^{3}$, AZHAR MA $^{4}$
}

\begin{abstract}
:
Poisoning is a common medico-social problem in our country causing around 300,000 episodes and around 2000 death per year. The number of poisoning cases is increasing in our country day by day. The common pattern of poisoning in our country is suicidal, homicidal/criminal and accidental. The incidence, nature, etiology, age group affected and the outcome of poisoning in our country is different from that of the western world. A prospective descriptive study of poisoning cases in Sir Salimullah Medical College and Mitford Hospital was attempted in 2004.

Among 100 cases, age of the cases ranged from 15-65 years. Sixty four percent were male. Around 68 percent cases were found businessman, 48\% were from low-income group and Fifty three percent cases were educated up to secondary level.

Among male patients $57.81 \%$ of poisoning caused by suspected sedative poisoning (transport related poison), $28.12 \%$ by organophophorous, 3.12\% by copper sulphate, 4.98 by benzodiazepines (attempted suicide), $4.98 \%$ by Acid and $1.56 \%$ by kerosene. Among female patients $41.66 \%$ of poisoning caused by organophosphorous compounds, $19.44 \%$ by rat killer, $11.11 \%$ by copper sulphate, $8.33 \%$ by benzodiazepines, $5.55 \%$ by acid, $5.55 \%$ by savlon, $5.55 \%$ by herpic and $2.77 \%$ by phenol.

Transport related poisoning by short acting sedative-hypnotics for the purpose of hijacking the belongings of the travelers and agrochemicals-organophosphorous compounds for suicidal purpose are the most common poisoning in our country. The pattern and magnitude of poisoning are thus multidimensional and demanding multi-sectoral approach for facing the problem. The comprehensive patient care can improve the poisoning case management in our country.
\end{abstract}

(J Dhaka Med Coll. 2008; 17(2) : 111-115)

\section{Introduction:}

Poisoning is a common medico-social problem now a days all over the world. It consumes not only the valuable health service resources but also cause considerable morbidity and mortality. In our country it causes around 300,000 episodes and around 2000 death per year. ${ }^{1}$ In the United States of America exposure to xenobiotics results in over 5 million request for medical advice and treatment each year and is the fourth most common cause of accidental death with the reported mortality is over 5000 per year. ${ }^{2,3}$ In the United Kingdom, it accounts for $13-20 \%$ of all medical emergency admission to hospital. ${ }^{4}$

A world wide analysis of acute intoxications was attempted trying to weight their medical and economic burden and the toll for acute poisoning in terms of morbidity and mortality. The natural history of acute intoxications reveals two common pattern, such as the increase in number and the changing profile of acute poisoning 5 .

The number of poisoning cases are increasing in our country day by day. The common pattern of poisoning in our country are suicidal, homicidal/criminal and accidental. The incidence, nature, aetiology, age group affected and the outcome of poisoning in our country is different from that of the western world. ${ }^{5,7}$

The poisoning agents involved in our country are different because of the social structure, economic status, educational level, awareness

1. Assistant Professor, Department of Medicine, Dhaka Medical College

2. Assistant Registrar, Department of Medicine, Dhaka Medical College

3. Associate Professor, Department of Medicine, Dhaka Medical College

4. Principal, Sir Salimullah Medical College, Dhaka

Correspondence: Dr. Md. Anisur Rahman Howlader 
of our people and availability of drugs are different from that of the western countries ${ }^{8}$.

Few studies done previously in our country shown that, the causes of poisoning in our country are lack of education, frustration, familial disharmony, failure of love affairs, failure in the examination and the availability of the poison. Common poisoning in our country are organophosphorous compound and street poisoning with ultra short acting sedativehypnotics 9,10 .

However pattern of poisoning and motive behind poisoning might have changed over the years, which needs further study. Such will help management and prevent poisoning in our country.

\section{Materials \& Methods}

Types of Study: Prospective study.

Place of study: Medicine units of Sir Salimullah Medical College \& Mitford Hospital (SSMC\&MH), Dhaka.

Period of Study: From January 2004 to June 2004

\section{Inclusion criteria:}

1. All the suspected poisoning cases admitted in medicine units, of Sir Salimullah Medical College \& Mitford Hospital, Dhaka were included in this study. A total 100 cases were studied.

2. Age more than 15 yrs

3. Patient or patient's attendant who gave consent.

\section{Exclusion criteria:}

1. Snake bite, food poisoning, and electrocution, near drowning, drug reaction are not included in this study.

2. Patientts with co-morbid conditions including metabolic causes and structural brain related causes were excluded.

3. Unwilling to give informed consent by patient or patients relatives.

\section{Data collection}

Patients admitted as suspected cases of poisoning through emergency and outdoor admission were initially screened by study physician. After doing the exclusion criteria detailed history and clinical examination were done in all enrolled cases. Diagnosis was made on the basis of patients statement, statement of the witness, smell of poisoning agents, brought specimen and characteristic features of poisoning in majority of cases (clusters of syndrome). Relevant investigations like RBS, CBC, SGPT, Serum Bilirubin, Prothrombin time, Blood Urea, Serum Creatinine, X-ray Chest was done to exclude other possibilities and to see the prognosis. Those having relevant investigation confirming other metabolic or structural causes were not included in the study and not analyzed therfore. All the data collected in data sheet. Informed written consent from the patient when conscious and from attendant when unconscious were taken before enrollment. According to the educational level all the patients were classified into three groups:

1. Primary: Those who were illiterate or educated only up to class five level.

2. Secondary: Those who were educated up to higher secondary level.

3. Graduate: Educated above higher secondary level.

The economic status of the patients were labeled according to monthly income (approximately). These were as follows:

Low income group: $<3,000$ taka per month

Middle income group: 3,000-10,000 taka per month

High income group: > 10,000 taka per month.

Ethical aspect / consent

Before study informed consent was taken from the patient/attendant and aims of the study were explain to them.

\section{Results:}

A total of 100 (male 64, female 36) cases were observed in the finding. Age of the cases ranged from 15-65 years. $40 \%$ were found in $36-45$ years of age group, 26\% were 26-35 years age group. Most of the affected people were between 20-45 years age group (table- I). Sex incidence of this table shows that most of the affected people were male $46(64 \%)$ and $36(36 \%)$ were 
female. Marital status shows that highest number $62(62 \%)$ of the patients were married, $20(20 \%)$ of were unmarried and $12(12 \%)$ were separated.

\section{Table- I} Age distribution of poisoning

\begin{tabular}{lcc}
\hline $\begin{array}{l}\text { Age range } \\
\text { in years }\end{array}$ & $\begin{array}{c}\text { Number } \\
\text { of patients }\end{array}$ & Percentage \\
\hline $15-25$ & 20 & 20 \\
$26-35$ & 26 & 26 \\
$36-45$ & 40 & 40 \\
$46-55$ & 10 & 10 \\
$56-65$ & 4 & 4 \\
\hline
\end{tabular}

In analysis of occupation of the victims, $67.56 \%$ were businessman, $16.21 \%$ were traveler (domestic), $10.81 \%$ were service holder and $5.40 \%$ were from different other categories (table-II). regarding economic status of the victims, $48 \%$ were from low income group, $47 \%$ from middle income and 5\% from high income group. Fifty three percent cases were educated up to secondary level, $40 \%$ were primary level and only $7 \%$ were above higher secondary level.

Table- II

Pattern of occupation of transport related poisoning patients $(n=37)$.

\begin{tabular}{lcc}
\hline Position & $\begin{array}{c}\text { Number } \\
\text { of patients }\end{array}$ & Percentage \\
\hline Businessman & 25 & 67.56 \\
Traveler & 6 & 16.21 \\
Service holder & 4 & 10.81 \\
Others & 2 & 5.40 \\
\hline
\end{tabular}

The pattern of poisoning in male patient shows that $57.81 \%$ of poisoning caused by suspected sedative poisoning (transport related poison), $28.12 \%$ by organophophorous, $3.12 \%$ by copper sulphate, 4.98 by benzodiazepines (attempted suicide), $4.98 \%$ by Acid and $1.56 \%$ by kerosene (table- III).

The pattern of poisoning in female patient shows that $41.66 \%$ of poisoning caused by organophophorous compounds, $19.44 \%$ by rat killer, 11.11 by coper sulphate, $8.33 \%$ by benzodiazepines, $5.55 \%$ by acid, $5.55 \%$ by savlon, $5.55 \%$ by herpic and $2.77 \%$ by phenol (table-IV).
Table- III

Shows pattern poisoning in male $(n=64)$.

\begin{tabular}{lcc}
\hline Types & $\begin{array}{c}\text { Number } \\
\text { of patients }\end{array}$ & Percentage \\
\hline $\begin{array}{l}\text { Transport related } \\
\text { poisoning' withsuspected }\end{array}$ & & \\
benzodiazepines & 37 & 57.81 \\
Organophosphorous (O.P.C) & 20 & 20 \\
Copper sulphate & 2 & 3.12 \\
Benzodiazepines & 3 & 4.98 \\
Acids & 3 & 4.98 \\
Kerosine & 1 & 1.56 \\
\hline
\end{tabular}

Table- IV

Pattern of poisoning in female $(n=36)$

\begin{tabular}{lcc}
\hline Types & $\begin{array}{c}\text { Number of } \\
\text { patients }\end{array}$ & Percentage \\
\hline Organophosphorous & 15 & 41.66 \\
Rat Killer & 7 & 19.44 \\
Copper Sulphate & 4 & 11.11 \\
Benzodiazepines & 3 & 8.33 \\
Acid & 2 & 5.55 \\
Savlon & 2 & 5.55 \\
Herpic & 2 & 5.55 \\
Phenol & 1 & 2.77 \\
\hline
\end{tabular}

\section{Discussion:}

In this study, poisoning of male (64\%) predominated over female $(36 \%)$ which was nearly similar to findings of Rashid et al ${ }^{9}, 11,12$. Among all the poisoning cases, homicidal 'transport related poisoning' by suspected short acting sedative or hypnotic drugs were the highest percentage (37\% of the total) and all were male. This finding are consistent with four previous study conducted in the Dhaka Medical College and District Hospital level ${ }^{13,14}$. But differ with the findings of other study ${ }^{10,11}$. Most of the poisoning occurs in the $3^{\text {rd }}$ and $4^{\text {th }}$ decade ( $40 \%$ of the total poisoning cases). Both suicidal and transport related poisoning are common in this group of people. Because they are the earning member of the family, so all the responsibilities (both financial and social) are exposed to them. They are the victim of poverty or any familial or social disharmony. 
In transport related poisoning these age group are commonly targeted, because the hijacker think that money is keep with them.

A large group of affected people were in young adult (30\% of total), which is similar to finding of Khan et a1.15,16,17,18 and most cases the motive behind poisoning in this age group were failure in affair, failure in the examination, sexual abuse etc. Overall these group people are emotionally labile and they are not mature enough to tolerate extreme mental or physical pressure.

Transport related poisoning by sedativehypnotics and datura ranked the highest among agents used for poisoning in this series (37\%). Datura was found as predominant agent used for stupefying purpose by Khan et al in 1985. ${ }^{19}$ But the situation has entirely changed. Only 4 patients out of 37 stupefying poisoning cases in this series had datura poisoning. All the remaining 33 were sedative-hypnotics poisoning applied to the travelers for the purposes of theft. This finding is nearly similar to the finding of Azhar et al in 1992 and Sarker et al in 2002 10, 20.

Most of victims of travel related poisoning were businessman (67.56\%) rest were normal/ domestic travelers (16.21\%) and few were service holder (10.81\%). Majority were from lower socio-economic classes. Possibly poor people move more frequently through bus and can be offered food more easily and easily approachable. Majority of people live hand to mouth and their educational status were also in the primary and secondary level. This finding closely resembles with the finding of other western countries ${ }^{21}$. The miscreants were deliberately mixing the poison with various foods for the purpose of theft. Initially they creates a relationship with the victim and then offered foods mixed with poison to them. Majority of people were made stuporous with dub water, soft drink, tea, banana, smaller parentage of victims were offered with betel leaf and nut, biscuits, jhal muri, friut juice etc.

The similar results were seen in a study in $\mathrm{CMCH}$ and in a hospital in New Delhi (Jain A. et al 2000) because these items were familiar with this group of victims, popular as fast food, cheaper to buy and easily available and widely accepted. Most of the victims were long route traveler. Sometimes poisons were forcefully offered to the victims and they compelled to ingest the poison. Most of the victims were transfer to the hospital emergency department by the police or helper of the bus or by accompanying person in the unconscious or semiconscious state.

Organophosphorous compound poisoning was the second leading causes of admission (33\%) in this series. Similar results found by five separate groups of authors in four separate study place ${ }^{15-18}$. OPC is commonly used as a suicidal poisoning by the poor rural people in the tropical Country ${ }^{22}$. Because this compounds are easily available in the rural agricultural based area. This indicates poverty, illiteracy and early marriage is an important contributing factor. Incidence of suicidal poisoning among married housewives was high indicating that they become the victim of domestic trouble, many being dowry related, this observation correlates with the finding of Azhar, Khan and Faiz et a1. ${ }^{10,19,23}$ But in western countries the type of poisoning is entirely different and the incidence of insecticide and pesticide poisoning is minimal. Barbiturate, alcohol and other sedative hypnotics are the most common offenders in suicidal poisoning. ${ }^{24}$

Other agents used for the suicide were rat killer, which was $7 \%$ of the with poisoning case. This finding is consistent with Sarker et $a 1^{20}$. This agents were mostly used by the poor female. Few of them were maidservant. Next were the copper sulphate ( $6 \%$ of the total) used as a suicidal agent commonly by the rural poor people. As copper sulphate is easily available in this area. It is used to protect the fungal infection in the feet and hands by the cultivators and used for ripening of the banana. Out of 6 cases, only one patient developed renal failure and hepatic dysfunction, other were recovered by conservative measure.

Occasionally Acids were used as a suicidal poisons. Though it is not easily available, it is found, who are engaged in jewelery business 
or works in a chemical industry. Occasionally it was taken accidentally.

Sometimes, sedatives ( $5 \%$ of the total) used as a suicidal agent. It was commonly used by educated and rich people (affluent people). This is, probably due to the knowledge among this class of people about the ability of these drugs to produce a peaceful death (Death in sleep), occasionally it was used due to emotional crisis or attempts to draw attention which was evidenced by taking in a minimal amount (only few tablets) and preserving the strip of the drugs.

Other agents used for suicidal purpose were herpic, savlon, kerosine, phenol etc. Also it was commonly used by the poor people mainly maid servant.

\section{Conclusion:}

Acute poisoning is a common and urgent medical problem in our country. Transport related poisoning by short acting sedativehypnotics for the purpose of hijacking the belongings of the travelers and agrochemicalsorganophosphorous compounds for suicidal purpose are the most common poisoning in our country. The pattern and magnitude of poisoning are thus multidimensional and demanding multi-sectoral approach for facing the problem. People involved in medical practice must be aware of pattern of the common poisoning agents as well as their management.

\section{Referrences}

1. M.J. Uddin, F.H. Shahed, M.A. Faiz. Transport Related Poisoning - An Untapped Public Health Problem. In Year Book 2002, Department of Medicine, CMC, Chittagong.

2. Litovitz TI et al. Annual Report of the American Association of Poison control centres Toxic exposure surveillance system. Am J Emerg Med. 1998; 16: 443.

3. Akhter F, Shahidullah M, Rahman MM. Study on poisoning cases Admitted at Jhenaidha Sadar Hospital. Northern Med J. 2000; 9(1): 14-20.

4. Sarkar ZM, Khan RK. Acute Poisoning- Scenario at a District Hospital. Bangladesh J. Medicine. 2002; 13(2):51.

5. Mannaim PF. Pattern of acute intoxication in Florence: A comparative investigation. Intensive Care Med. 1991; 17(1): 24-31.

6. Begum JA, Chowdhury MM. G Ara. A study of poisoning cases in four hospitals of Bangladesh. Bangladesh Med J. 1989; 18(2): 64.
7. Khan NI, Sen N, Hague NA. Poisoning in a medical unit of Dhaka Medical College Hospital in 1983. Bangladesh Med J. 1985; 14(1):9-12.

8. Ahmed R. Shah R, Mortayezamin MM. Pattern and mortality rate of poisoning in Dhaka Medical College Hospital. J. Med Teachers' Fed. 1995; 1(1): 10-12.

9. Hossain AKMM, Hannan MA, Janan FAJ clinical pattern and outcome poisoning- A study in medical indoor of a teaching hospital. Bangladesh $\mathrm{J}$ Med 1999; 10(1): 27-29.

10. Azhar MA. Poisoning cases in a district hospital of Bangladesh. JOPSOM, 1992; 11(2): 69-72.

11. Lawson AAH. Acute poisoning. In: Edwards CRW, Bouchier IAD, Haslett C, Chilvers E editors. Davidson's Principles and Practice of Medicine. 1995: 1126.

12. Ahmed R, Shah R, Parvin S, Dey DK. Pattern and Mortality rate of poisoning in Dhaka Medical College Hospital. J Med Teachers' Fed. 1995; (1): 10-12.

13. Sarker ZM, Khan RK, Acute Poisoning - Scenario at a district hospital. Bangladesh J Med. 2002; 13: 49-52.

14. Prince-BS, Goetz CM, Rihn TL. Olsky-M. Drugrelated emergency deptt. visits and hospital admission (abstract). Am J Hosp Pharm. 1992; 47(7): 1696-700.

15. Tabib SB, Pal UK. A study of acute poisoning cases in a district hospital. Northern Med J. 1992; 1(1): $1-5$.

16. Rahman M, Rahman M, Chowdhury AH. Pattern of poisoning in Rangpur Medical College Hospital. Northern Med J. 1994; 3(2): 15-18.

17. Meredith Tm. Epidemiology of poisoning In : Vale A, Proudfoot A, Stray J, William G, Mallick NP editors. Medicine International. 1995; 9(29): 1-2, 42, 409.

18. Bakar MA, Ahsan SMM, Chowdhury PK. Acute poisoning-nature and outcome of treatment in a teaching hospital. Bangladesh Med Assoc. (Khulna), 1999; 32(1): 19-21.

19. Khan NI, Sen N, Haque NA. Poisoning in a medical unit of Dhaka Medical College Hospital in 1983. Bangladesh Med J. 1985; 14(1): 9-1.

20. Sacker ZM., Khan RK. Acute poisoning- scenario at a district hospital, Bangladesh J Med. 2002; 13:49-52.

21. Gelder M, Gath D and Mayou R. Oxford Textbook of psychiatry, $2^{\text {nd }}$ edn, Oxford University Press, Oxford 1989; 494.

22. Jeyaratnam, J. Health problems of pesticide usage in the third world. Br J Int Med. 1985; 42:505-506.

23. Faiz MA. Organophosphours compound intoxication. Medical Digest, 1981; 62-63.

24. Olson KR, Dreisbach RH. Poisoning. In current medical diagnosis and treatment ed. By Schronder SA, Knup MA, Tierry LM. California: Lange medical publication; 1988. p. 1013-1034. 